\title{
Front Matter: Volume 10408
}

, "Front Matter: Volume 10408," Proc. SPIE 10408, Laser Communication and Propagation through the Atmosphere and Oceans VI, 1040801 (14 November 2017); doi: $10.1117 / 12.2296003$

EDent: SPIE Optical Engineering + Applications, 2017, San Diego, California, SPIE. United States 


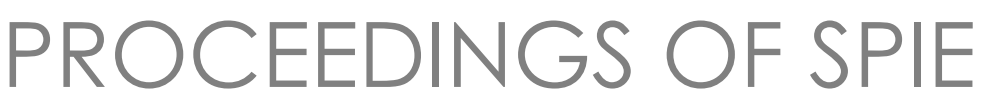

\section{Laser Communication and Propagation through the Atmosphere and Oceans VI}

Jeremy P. Bos

Alexander M. J. van Eijk

Stephen M. Hammel

Editors

8-9 August 2017

San Diego, California, United States

Sponsored and Published by

SPIE

Volume 10408 
The papers in this volume were part of the technical conference cited on the cover and title page. Papers were selected and subject to review by the editors and conference program committee. Some conference presentations may not be available for publication. Additional papers and presentation recordings may be available online in the SPIE Digital Library at SPIEDigitalLibrary.org.

The papers reflect the work and thoughts of the authors and are published herein as submitted. The publisher is not responsible for the validity of the information or for any outcomes resulting from reliance thereon.

Please use the following format to cite material from these proceedings:

Author(s), "Title of Paper," in Laser Communication and Propagation through the Atmosphere and Oceans VI, edited by Jeremy P. Bos, Alexander M. J. van Eijk, Stephen M. Hammel, Proceedings of SPIE Vol. 10408 (SPIE, Bellingham, WA, 2017) Seven-digit Article CID Number.

ISSN: 0277-786X

ISSN: 1996-756X (electronic)

ISBN: 9781510612730

ISBN: 9781510612747 (electronic)

Published by

SPIE

P.O. Box 10, Bellingham, Washington 98227-0010 USA

Telephone +1 3606763290 (Pacific Time) · Fax +1 3606471445

SPIE.org

Copyright (c) 2017, Society of Photo-Optical Instrumentation Engineers.

Copying of material in this book for internal or personal use, or for the internal or personal use of specific clients, beyond the fair use provisions granted by the U.S. Copyright Law is authorized by SPIE subject to payment of copying fees. The Transactional Reporting Service base fee for this volume is $\$ 18.00$ per article (or portion thereof), which should be paid directly to the Copyright Clearance Center (CCC), 222 Rosewood Drive, Danvers, MA 01923. Payment may also be made electronically through CCC Online at copyright.com. Other copying for republication, resale, advertising or promotion, or any form of systematic or multiple reproduction of any material in this book is prohibited except with permission in writing from the publisher. The CCC fee code is 0277$786 \mathrm{X} / 17 / \$ 18.00$.

Printed in the United States of America.

Publication of record for individual papers is online in the SPIE Digital Library.

\section{SPIE. DIGITAL}

Paper Numbering: Proceedings of SPIE follow an e-First publication model. A unique citation identifier (CID) number is assigned to each article at the time of publication. Utilization of CIDs allows articles to be fully citable as soon as they are published online, and connects the same identifier to all online and print versions of the publication. SPIE uses a seven-digit CID article numbering system structured as follows:

- The first five digits correspond to the SPIE volume number.

- The last two digits indicate publication order within the volume using a Base 36 numbering system employing both numerals and letters. These two-number sets start with $00,01,02,03$, 04, 05, 06, 07, 08, 09, OA, OB ... 0Z, followed by 10-1Z, 20-2Z, etc. The CID Number appears on each page of the manuscript. 


\title{
Contents
}

\author{
vii Authors \\ ix Conference Committee
}

\section{SESSION 1 FREE SPACE OPTICAL COMMUNICATIONS I}

1040802 Testing of a compact 10-Gbps Lasercomm system for maritime platforms (Invited Paper) [10408-1]

1040803 Phase and amplitude modification of a laser beam by two deformable mirrors using conventional 4 image encryption techniques [10408-2]

1040804 Design and flight test results of high speed optical bidirectional link between stratospheric platforms for aerospace applications [10408-3]

1040805 Overwater ultraviolet non-line-of-sight communication channel modeling and analysis [10408-5]

\section{SESSION 2 FREE SPACE OPTICAL COMMUNICATIONS II}

1040807 Performance analysis of stationary Hadamard matrix diffusers in free-space optical communication links [10408-7]

1040808 Simulating the performance of adaptive optics techniques on FSO communications through the atmosphere [10408-8]

\section{SESSION 3 BEAM PROPAGATION}

10408 0A Atmospheric propagation of coherently and incoherently combined quantum cascade lasers (Invited Paper) [10408-10]

10408 OB Study on the effect of anisotropy on a propagating beam [10408-11]

10408 OD Analysis of the covariance function and aperture averaged fluctuations of irradiance to calculate $\mathrm{C}^{2}{ }^{2}$ [10408-13]

10408 OE Optimization of wavefront-sensorless adaptive optics for horizontal laser beam propagation in a realistic turbulence environment [10408-14]

\section{SESSION 4 AIRBORNE SATELLITE APPLICATIONS}

10408 OF Cloud free optical link probabilities to satellites from multiple ground stations [10408-15] 
10408 OG Modeling of ground based laser propagation to low Earth orbit object for maneuver [10408-16]

10408 Ol Polarized photon transport through fog [10408-47]

\section{SESSION 5 ORBITAL ANGULAR MOMENTUM}

10408 OK OAM of beam waves in random inhomogeneous medium [10408-20]

$10408 \mathrm{OL}$ Shack-Hartmann measurements of the transverse linear and orbital angular momenta after propagation through turbulence [10408-21]

\section{SESSION 6 IMAGE DEBLURRING}

10408 OM Image blurring due to turbulent wakes for airborne systems: flight tests [10408-22]

10408 ON Image blurring due to turbulent wakes for airborne systems: simulation and modeling [10408-23]

\section{SESSION 7 ATMOSPHERIC CHARACTERIZATION I}

10408 OP Atmospheric characterization on the Kennedy Space Center Shuttle Landing Facility [10408-25]

$104080 Q$ A machine learning approach for predicting atmospheric aerosol size distributions [10408-26]

10408 OR Climatological assessment of maritime atmospheric profiles: model-based and LIDARbased approaches [10408-27]

\section{SESSION 8 ATMOSPHERIC CHARACTERIZATION II}

10408 OT Determination of accurate vertical atmospheric profiles of extinction and turbulence [10408-29]

10408 OU Investigation of the height dependency of optical turbulence in the surface layer over False Bay (South Africa) [10408-30]

10408 OV In-situ and path-averaged measurements of aerosol optical properties [10408-31]

10408 OW Determination of the spectral behaviour of atmospheric soot using different particle models [10408-32]

\section{SESSION 9 HORIZONTAL IMAGING AND BEAM PROPAGATION}

10408 0X Saturation of the anisoplanatic error in horizontal imaging scenarios [10408-33]

iv 
10408 OY Hybrid wavefront sensing and image correction algorithm for imaging through turbulent media [10408-34]

$10408 \mathrm{OZ}$ Numerical simulation and analysis of aero-optical effect of the 3D side window [10408-36]

POSTER SESSION

1040810 Hemispherical optical dome for underwater communication [10408-4]

1040811 Coherent optical communication detection device based on modified balanced optical phase-locked loop [10408-37]

1040812 The integration of laser communication and ranging [10408-38]

1040813 Radial partially coherent beams for free-space optical communications [10408-39]

1040814 A variable rate communicate method for self-differential coherent DPSK [10408-40]

1040815 Optical axis stability system based on acousto-optic deflector [10408-41]

1040816 Fine track system of space coherent optical communication without position detector [10408-42]

1040818 Multiple wavelength spectral system simulating background light noise environment in satellite laser communications [10408-44] 
Proc. of SPIE Vol. 10408 1040801-6

Downloaded From: https://www.spiedigitallibrary.org/conference-proceedings-of-spie on 26 Apr 2023 Terms of Use: https://www.spiedigitallibrary.org/terms-of-use 


\section{Authors}

Numbers in the index correspond to the last two digits of the seven-digit citation identifier (CID) article numbering system used in Proceedings of SPIE. The first five digits reflect the volume number. Base 36 numbering is employed for the last two digits and indicates the order of articles within the volume. Numbers start with 00, 01, 02, 03, 04, 05, 06, 07, 08, 09, OA, OB...0Z, followed by 10-12, 20-2Z, etc.

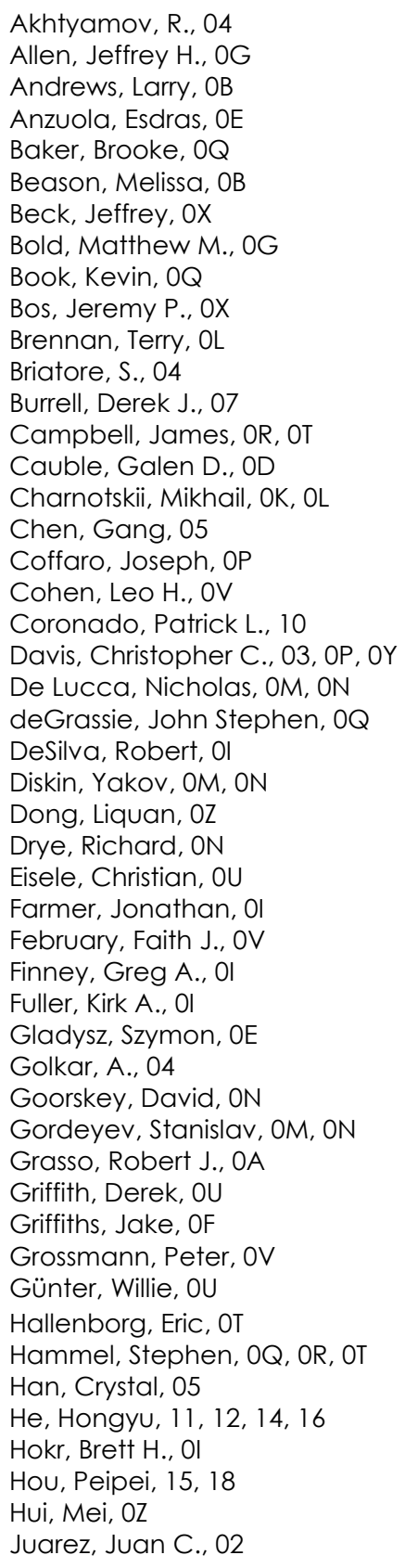

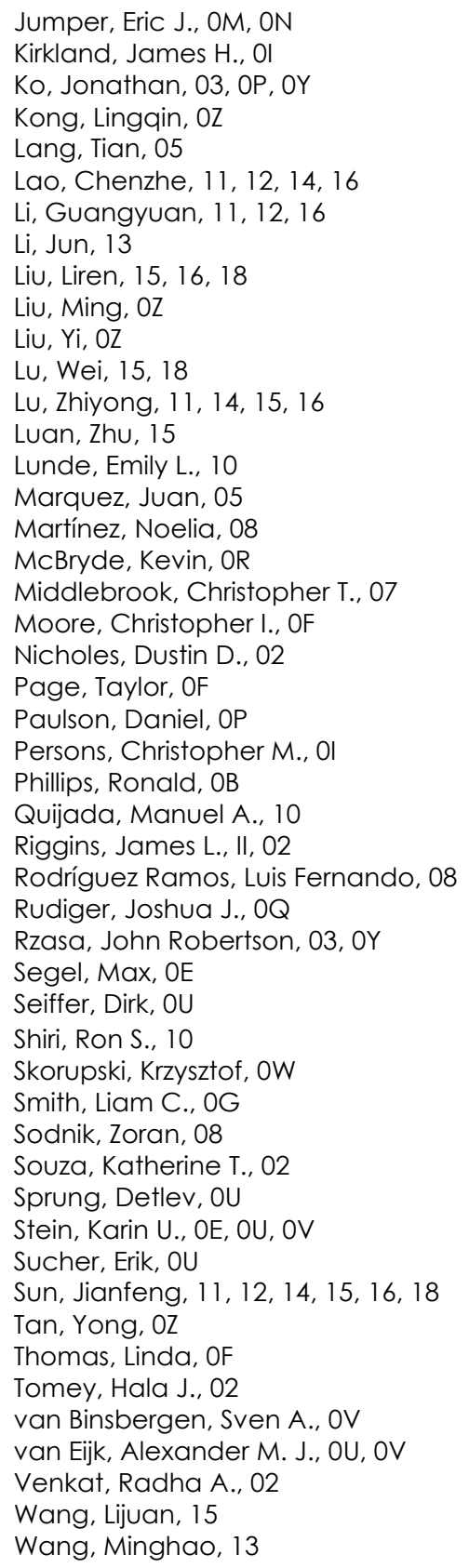


Wayne, David T., OD

Whiteley, Matthew R., OM, ON

Willstatter, Lindsey, OF

Wu, Chensheng, 03, OP, OY

$\mathrm{Xi}$, Yueli, 15, 18

$X u$, Mengmeng, 11, 12, 14, 16

$X u$, Qian, 15, 16, 18

Yuan, Xiuhua, 13

Zepp, Andreas, OE

Zhang, Bo, 11, 12, 14, 16

Zhang, Guo, 11, 12, 14, 16

Zhao, Yuejin, $\mathrm{OZ}$

Zhou, Xiaoxin, 13

Zhou, Yu, 12, 15, 16, 18

Zhu, Funan, 15, 18 


\section{Conference Committee}

Program Track Chairs

Stephen M. Hammel, Space and Naval Warfare Systems Command (United States)

Alexander M. J. van Eijk, TNO Defence, Security and Safety

(Netherlands)

Conference Chairs

Jeremy P. Bos, Michigan Technological University (United States)

Alexander M. J. van Eijk, TNO Defence, Security and Safety (Netherlands)

Stephen M. Hammel, Space and Naval Warfare Systems Command (United States)

Conference Program Committee

Larry C. Andrews, University of Central Florida (United States)

Jaime Anguita, Universidad de Los Andes (Chile)

Shlomi Arnon, Ben-Gurion University of the Negev (Israel)

Sukanta Basu, Delft University of Technology (Netherlands)

Matthew M. Bold, Lockheed Martin Space Systems Company (United States)

Mikhail I. Charnotskii, MC Consulting (United States)

Gang Chen, University of California, Riverside (United States)

Christopher C. Davis, University of Maryland, College Park (United States)

Robert J. Grasso, RJG Consulting (United States)

Jony Jiang Liu, U.S. Army Research Laboratory (United States)

Arun K. Majumdar, Naval Air Warfare Center Weapons Division (United States)

Vladimir B. Markov, Advanced Systems \& Technologies, Inc. (United States)

Dominic C. O'Brien, University of Oxford (United Kingdom)

Ronald L. Phillips, Florida Space Institute (United States)

William S. Rabinovich, U.S. Naval Research Laboratory (United States)

Karin Stein, Fraunhofer-Institut für Optronik, Systemtechnik und Bildauswertung (Germany)

Miranda van lersel, TNO Defence, Security and Safety (Netherlands)

Thomas Weyrauch, University of Dayton (United States)

Otakar Wilfert, Brno University of Technology (Czech Republic)

Heba Yuksel, Bogaziçi University (Turkey) 


\section{Session Chairs}

1 Free Space Optical Communications I

Alexander M. J. van Eijk, TNO Defence, Security and Safety

(Netherlands)

Stephen Hammel, Space and Naval Warfare Systems Command (United States)

2 Free Space Optical Communications II

Jeremy P. Bos, Michigan Technological University (United States)

Robert J. Grasso, EOIR Technologies (United States)

3 Beam Propagation

Stephen Hammel, Space and Naval Warfare Systems Command (United States)

Liam Smith, Lockheed Martin Space System Company (United States)

4 Airborne Satellite Applications

Jeremy P. Bos, Michigan Technological University (United States)

Jaime A. Anguita, Universidad de los Andes (Chile)

5 Orbital Angular Momentum

Jeremy P. Bos, Michigan Technological University (United States)

Chensheng Wu, University of Maryland, College Park (United States)

6 Image Deblurring

John S. deGrassie, SPAWAR Systems Center Pacific (United States)

Christopher C. Davis, University of Maryland, College Park (United States)

7 Atmospheric Characterization I

Stephen Hammel, Space and Naval Warfare Systems Command (United States)

Mikhail I. Charnotskii, MC Consulting (United States)

8 Atmospheric Characterization II

Chensheng Wu, University of Maryland, College Park (United States)

Christopher C. Davis, University of Maryland, College Park (United States)

9 Horizontal Imaging and Beam Propagation

Jeremy P. Bos, Michigan Technological University (United States)

Alexander M. J. van Eijk, TNO Defence, Security and Safety

(Netherlands) 